\title{
FORMULASI SEDIAAN SABUN PADAT DARI MINYAK NILAM (Pogostemon cablin Benth)
}

\author{
Nirwati Rusli \\ Program Studi DIII Farmasi Politeknik Bina Husada Kendari \\ Email : nirwatirusli@gmail.com
}

\begin{abstract}
Solid soap is a soap made from fat saponification reaction of solid sodium hydroxide, which is used to cleanse the body. Patchouli essential oil content of patchouli alcohol discount antibacterial and anti-inflammatory. One dosage appropriate to formulate patchouli essential oils to antibacterial soap is in the form of a solid. This research aims to create a solid soap preparation patchouli essential oils as antibacterial soap. Research conducted an experiment with solid soap making preparations to test a physical evaluation of solid soap include organoleptic test is the color, shape and scent, $\mathrm{pH}$ test, test foam height and stability test (cycling test). The results showed that the preparations are made which have different colors and scents are the same, because the process used for solid soap that is by the saponification reaction for 2 hours with temperature $70-80^{\circ} \mathrm{C}$, with the variation of patchouli essential oil $1 \%, 2 \%, 3 \%(b / b)$ as an ingredient additives and make use of the type of $\mathrm{NaOH}$. From the result of the concentration of essential oils nilam varied, which makes different colors with the same scent, obtained pH between 7.77 to 9.70 with a height of $9 \mathrm{~cm}$ foam inside.
\end{abstract}

Key words : Patchouli oil, saponification, solid soap, coconut oil.

\section{PENDAHULUAN}

Tanaman nilam merupakan salah satu tanaman penghasil minyak atsiri utama di Indonesia dan memiliki nilai ekonomi tinggi. Indonesia merupakan Negara pensuplai minyak nilam terbesar di pasaran dunia, hamper $70 \%$ dari total kebutuhan minyak nilam dunia berasal dari Indonesia. Sedangkan Negara penghasil nilam lainnya adalah dari
Cina. ${ }^{1}$ Jenis tanaman nilam varietas pogostemon cablin Benth, sebenarnya dari Filipina yang kemudian berkembang ke Malaysia dan Indonesia. ${ }^{2}$

Tanaman nilam sebagai salah satu penghasil minyak atsiri merupakan salah satu komoditas ekspor andalan minyak atsiri Indonesia dan mempunyai prospek yang baik karena dibutuhkan secara terus menerus dalam industri 
seperti : pembuatan parfum, sabun, sediaan farmasi dan kosmetik lainnya. ${ }^{3}$ Minyak nilam diperoleh dari hasil penyulingan daun, batang, dan cabang tanaman nilam. Kadar minyak tertinggi terdapat pada daun dengan kandungan utamanya adalah patchouli alkohol yang berkisar antara $30-50 \%$. Aromanya segar dan khas serta mempunyai daya fiksasi yang kuat, sulit digantikan oleh bahan sintetis. ${ }^{4}$ Umumnya, kandungan minyak atsiri pada akar, batang dan ranting tanaman nilam lebih kecil (0,4-0,5\%) dibandingkan kandungan minyak atsiri pada bagian daun $(2,5-5,0 \%){ }^{5}$

Berdasarkan penelitian, minyak nilam terbukti dapat menghambat pertumbuhan bakteri staphylococcus aureus pada konsentrasi $30 \%$. Semakin besar konsentrasi minyak nilam maka semakin besar pula senyawa aktif sebagai antibakteri yang terkandung dalam minyak atsiri nilam, sehingga daya hambatnya besar. ${ }^{6}$

Minyak nilam biasanya digunakan sebagai fiksatif (pengikat) dalam industri parfum dan merupakan salah satu campuran pembuatan produk kosmetik seperti sabun, pasta gigi, shampo, lotion, deodoran dan tonik rambut. ${ }^{5}$ Sehingga salah satu cara untuk mengembangkan penggunaan zat aditif minyak nilam sebagai zat pengikat dan antibakteriperlu dikembangkan menjadi produk kosmetik seperti sabun.

Sabun dihasilkan oleh proses saponifikasi, yaitu hidrolisis lemak menjadi asam lemak dan gliserol dalam kondisi basa. Kondisi basa diperoleh dari $\mathrm{NaOH}$ atau $\mathrm{KOH}$.Asam lemak yang berikatan dengan natrium atau kalium inilah yang kemudian dinamakan sabun. Sabun umumnya dikenal dalam dua wujud, sabun cair dan sabun padat.Perbendaan utama dari kedua wujud sabun ini adalah alkali yang digunakan dalam reaksi pembuatan sabun.Sabun padat menggunakan natrium hidroksida $(\mathrm{NaOH})$ sedangkan sabun cair menggunakan kalium hidroksida $(\mathrm{KOH})$ sebagai alkali. ${ }^{7}$ 


\section{METODE PENELITIAN}

Tabel 1. Formula sediaan sabun padat minyak nilam

\begin{tabular}{cccc}
\hline \multirow{2}{*}{ Bahan } & \multicolumn{3}{c}{ Formula (\%) } \\
\cline { 2 - 4 } & FA & FB & FC \\
\hline Minyak Nilam & 1 & 2 & 3 \\
Minyak Kelapa & 12 & 12 & 12 \\
Gliserin & 12 & 12 & 12 \\
NaOH & 7 & 7 & 7 \\
Asam Sitrat & 5 & 5 & 5 \\
NaCl & 1.5 & 1.5 & 1.5 \\
Akuades & $50 \mathrm{~mL}$ & $50 \mathrm{~mL}$ & $50 \mathrm{~mL}$ \\
\hline
\end{tabular}

Penelitian dilakukan secara lemari pendingin, oven, $\mathrm{pH}$ meter, eksperimen, sampel minyak nilam. timbangan, termometer, wadah. Kemudian diformulasi menjadi sediaan Adapun bahan-bahan yang akan sabun padat dengan memvariasikan digunakan adalah akuades, minyak konsentrasi minyak nilam 1\%, $2 \%$ nilam, $\mathrm{NaOH}$, asam stearat, gliserin, dan3\%. Setelah sabun padat dibuat minyak kelapa, dan NaCL. Pengolahan kemudian dilakukan uji evaluasi fisik data pada penelitian ini dilakukan sediaan yang meliputi uji organoleptik yaitu warna, bentuk dan aroma, uji $\mathrm{pH}$, uji tinggi busa dan uji stabilitas. Adapun alat-alat yang akan digunakan dalam penelitian ini adalah batang pengaduk, dengan metode deskriptif.Data disajikan secara sederhana, yakni dalam bentuk tabelkemudian dijabarkan dalam bentuk narasi dan kesimpulan.

cetakan sabun, gelas kimia, hot plate,

\section{HASIL PENELITIAN}

Tabel 2. Hasil uji organoleptik sediaan sabun padat minyak nilam

\begin{tabular}{cccc}
\hline \multirow{2}{*}{ Organoleptik } & \multicolumn{3}{c}{ Formula sediaan sabun padat minyak nilam } \\
\cline { 2 - 4 } & FA & FB & FC \\
\hline Warna & Putih tulang & Putih Kecoklatan & Krem \\
Aroma & Khas Nilam & Khas Nilam & Khas Nilam \\
Bentuk & Padat & Padat & Padat \\
\hline
\end{tabular}


Tabel 3. Hasil uji stabilitas sediaan sabun padat minyak nilam

\begin{tabular}{cccccccc}
\hline \multirow{2}{*}{$\begin{array}{c}\text { Minyak } \\
\text { Nilam }\end{array}$} & \multirow{2}{*}{ Organoleptik } & \multicolumn{7}{c}{ Siklus Cycling test ke- } \\
\cline { 3 - 7 } & & I & II & III & IV & V & VI \\
\hline \multirow{2}{*}{$1 \%$} & Warna & Putih & Putih & Putih & Putih & Putih & Putih \\
& Bulang & Tulang & Tulang & Tulang & Tulang & Tulang \\
& Bentuk & Padat & Padat & Padat & Padat & Padat & Padat \\
& Aroma & Nilam & Nilam & Nilam & Nilam & Nilam & Nilam \\
\hline \multirow{2}{*}{$2 \%$} & Warna & Putih & Putih & Putih & Putih & Putih & Putih \\
& Bentuk & Padat & Padat & Padat & Padat & Padat & Padat \\
& Aroma & Nilam & Nilam & Nilam & Nilam & Nilam & Nilam \\
\hline \multirow{2}{*}{$3 \%$} & Warna & Krem & Krem & Krem & Krem & Krem & Krem \\
& Bentuk & Padat & Padat & Padat & Padat & Padat & Padat \\
& Aroma & Nilam & Nilam & Nilam & Nilam & Nilam & Nilam \\
\hline
\end{tabular}

Tabel 4. Hasil uji pH sediaan sabun padat minyak nilam

\begin{tabular}{cccc}
\hline \multirow{2}{*}{ Minggu } & \multicolumn{3}{c}{ Hasil uji pH } \\
\cline { 2 - 4 } & FA & FB & FC \\
\hline I & 9,53 & 7,81 & 7,77 \\
II & 9,67 & 7,84 & 7,79 \\
III & 9,69 & 7,87 & 7,80 \\
IV & 9,70 & 7,90 & 7,83 \\
\hline
\end{tabular}

Tabel 5. Hasil uji tinggi busa sediaan sabun padat minyak nilam

\begin{tabular}{cccc}
\hline \multirow{2}{*}{ Minggu } & \multicolumn{3}{c}{ Hasil uji tinggi busa (cm) } \\
\cline { 2 - 4 } & FA & FB & FC \\
\hline I & 4 & 6 & 9 \\
II & 4 & 6 & 9 \\
III & 4 & 6 & 9 \\
IV & 4 & 6 & 9 \\
\hline
\end{tabular}

\section{PEMBAHASAN}

Dari tabel 2 hasil uji organoleptik dapat dilihat ketiga formula yang memiliki warna yang berbeda-beda karena disebabkan minyak nilam yang berwarna kuning kecoklatan, maka semakin tinggi konsentrasi minyak nilam semakin cerah warna sediaan yang dihasilkan. Hal ini disebabkan karena kandungan senyawa Fe yang terkandung didalamnya lebih tinggi. ${ }^{8}$ Serta bentuk dan bau yang dihasilkan 
tidak mengalami perubahan selama penyimpanan.

Dari hasil pengamatan cycling test sediaan sabun padat secara visual sebelum dan setelah perlakuan cyclingtest menunjukkan bahwa sabun padatminyak nilam dengan konsentrasi $1 \%$, $2 \%$, dan $3 \%$ tidak mengalami perubahan fisiksetelah cyclingtest maupun sebelum cycling test. Hal ini menunjukkan bahwa ketiga formula stabil selama 12 hari penyimpanan (Tabel 3).

Hasil pengujian $\mathrm{pH}$ sediaan pada penyimpanan suhu kamar selama 4 minggu mengalami perubahan yang tidak signifikan setiap minggunya. Dapat diliat dari ketiga formulasi bahwa semakin tinggi konsentrasi minyak nilam semakin rendah $\mathrm{pH}$ sediaan yang didapatkan, dimana $\mathrm{pH}$ yang di peroleh adalah sebesar 7,77-9,80. Hal ini terjadi karena sebagian besar minyak nilam merupakan asam lemah atau netral ${ }^{9}$ (Tabel 4).

Hasil pengamatan uji tinggi busa sediaan sabun padat pada tabel diatas menunjukan sediaan sabun padat mengalami tingkat busa yang sangat tinggi pada formula $\mathrm{C}$ disebabkan karena minyak kelapa dan minyak nilam yang sangat tinggi dapat mempengaruhi tingkat busa yang dihasilkan dimana minyak kelapa kaya asam lemak berantai sedang $\left(\mathrm{C}_{8}-\mathrm{C}_{14}\right)$. Khususnya asam laurat dan asam meristat. Asam laurat sangat diperlukan dalam pembuatan sabun karena asam laurat mampu memberikan sifat pembusaan yang baik untuk produk sabun ${ }^{10}$. Komponen kimia penyusun minyak nilam terdiri dari dua golongan yaitu golongan hidrokarbon yang berupa senyawa seskueterpen, berjumlah sekitar 40$45 \%$ dari berat minyak dan golongan hidrokarbon beroksigen yang berjumlah sekitar $52-57 \%$ dari berat minyak ${ }^{9}$ (Tabel 5).

\section{KESIMPULAN}

Berdasarkan hasil penelitian yang dilakukan diperoleh kesimpulan bahwa Minyak nilam dapat dibuat menjadi sediaan sabun padat yang memenuhi syarat evaluasi fisik dengan menggunakan konsentrasi $1 \%, 2 \%$, dan 3\%.Dari ketiga formula sediaan sabun padat minyak nilam yang dihasilkan, konsentrasi minyak nilam $1 \%$, $2 \%$, dan $3 \%$ memenuhi syarat evaluasi fisik sediaan yang stabil.

\section{DAFTAR PUSTAKA}

1. Herlina, Betty. Pengaruh Volume Air Dan Berat Bahan Pada Penyulingan Minyak Atsiri; 2006.

2. Harahap. Konsentrasi dan simplisia dan isolasi serta analisis komponen minyak atsiri pada daun nilam; 2009.

nilam 
(http://repository.usu.ac.id/bitstrea $\mathrm{m} / 123456789 / 14328 / 1 / 09 E 01539 . p$ df).

3. Nuryani Y. Budidaya Tanaman Nilam. Di dalam Makalah Pembekalan Teknis untuk Rintisan Pengembangan Usaha Tani dan Fasilitasi Penumbuhan Kelompok Usaha Tani Tanaman Penghasil Minyak Atsiri. Balai Penelitian Tanaman Rempah dan Aromatik. Pusat Penelitian dan Pengembangan Perkebunan. Bogor; 2006.

4. Rusli S. Peningkatan mutu minyak nilam. Prosiding Pengembangan Tanaman Atsiri di Sumatera, Bukittinggi; 1991 Agustus 4; Bogor. Balai Penelitian Tanaman Rempah dan Obat; 1991; p.89-96.

5. Kardinan A. Tanaman Penghasil Minyak Atsiri. Jakarta : PT Agromedia Pustaka, 2005.

6. Dzakwan, M. Uji Aktivitas Antibakteri Minyak Atsiri Daun Nilam (Pogostemon cablin Benth)
Terhadap Staphylococcus aureus dan Eschericia coli. Surakarta : Fakultas IImu Kesehatan Universitas Setia Budi. 2008; 1:2.

7. Litro. Formula Sabun Transparan Antijamur Dengan Bahan Aktif Ekstrak Lengkuas. Jurnal Teknologi Industri. Fakultas Teknologi IPB; 2010; $21: 2$.

8. Pocut N.A. Aplikasi Proses Pengkelatan Untuk Peningkatan Mutu Minyak Nilam Aceh. Jurnal Rekayasa; 2007.

9. Guenther E. Minyak Atsiri Jilid IV. Diterjemahkan Oleh Ketaren, UIPress. Jakarta; 1990.

10. Baiq RM, Yeti K, dan Ahmadi. Pengaruh Konsentrasi $\mathrm{NaOH}$ Terhadap Kualitas SabDun Padat Dari Minyak kelapa (Cocos nucifera) Yang Ditambahkan Sari Bunga Mawar (Rosa L.). Mataram : Pendidikan Kimia, FMIPA IKIP, 2014;1:1. 